\title{
COM AÇÚCAR, COM AFETO: UM OLHAR ANTROPOLÓGICO SOBRE RITUAIS MATRIMONIAIS A PARTIR DE SUAS MESAS DE DOCES*
}

Cristina Teixeira Marins

\section{Introdução}

Eu fazia trabalho de campo quando um casal de jovens que se via às voltas com os preparativos de seu casamento compartilhou comigo um relato ao qual se referiam jocosamente como "a novela dos doces". Tudo começou, segundo eles, cerca de seis meses antes da data do casamento. Àquela altura já tinham sido tomadas decisões que eles classificavam como "as mais importantes" do casamento: a complexa tarefa de elaborar a lista de convidados tinha sido concluída com êxito, um profissional já havia sido contratado para cuidar dos registros fotográficos do evento e os noivos já tinham providenciado um juiz de paz que conduziria a cerimônia. Uma costureira se ocupava do vestido da noiva e uma decoradora trabalhava no projeto de ornamentação da mansão em estilo neoclássico escolhida para abrigar os festejos. Também já havia sido contratada uma empresa de buffet que cuidaria do almoço servido na ocasião.

Considerando encerrada "a parte mais difícil" dos preparativos, nosso casal de noivos passou então a cuidar do que eles chamavam de "detalhes" do casamento. Dentre outras coisas, era preciso providenciar um buquê de flores para a noiva, escolher os convites e encomendar docinhos. Eles se declaravam confiantes de que não encontrariam dificuldades nesta etapa, primeiro, porque existiam inúmeros profissionais disponíveis no mercado dentre os quais poderiam escolher e, segundo, porque eles se julgavam pessoas dotadas de imenso espírito prático, capazes de tomar decisões de maneira objetiva e descomplicada.

A tarefa de pedir orçamentos de doces, no entanto, se revelou mais complexa do que eles poderiam supor. De partida, eles se viam perdidos em relação às quantidades de doces que deveriam ser encomendados. Além 
disso, escolher dentre as opções disponíveis - muito mais numerosas do que eles poderiam até então suspeitar - lhes parecia constituir tarefa inglória. Isto sem contar com o custo destes itens, inexplicavelmente alto, segundo eles.

Partiu da noiva a solução para o impasse dos doces. Com ar triunfante, ela contou que no lugar dos "doces tradicionais de casamento" trataria de providenciar uma grande mesa de compotas. Estas seriam exibidas em jarras de vidro contendo quitutes como doce de leite, goiabada cremosa, ambrosia e doce de abóbora. A mesa "inovadora", dizia ela entusiasmada, custaria muito menos do que uma mesa repleta de "doces de casamento" e, além disso, os convidados poderiam nela se fartar, já que a noiva considerava estas iguarias deveras democráticas: "quem é que não gosta de doces de compotas?".

Ocorre que a mãe da noiva, assim que soube de seus planos, achou por bem interceder em defesa da mesa de doces. Argumentando que casamento "sem mesa de doces não é casamento", tratou de exigir que a noiva encomendasse "doces finos". Embora o casamento em questão estivesse sendo financiado pelos próprios noivos, a mãe se dispôs a pagar pelas iguarias caso fosse "um problema de dinheiro". Em pouco tempo a polêmica se instalou entre os membros da família e enquanto os irmãos e o pai da noiva concordavam que a mesa de compotas era mais do que satisfatória, a mãe da noiva e suas tias indagavam insistentemente: "Onde já se viu casamento sem mesa de doces?".

Disposta a encerrar a contenda familiar que se arrastava por semanas, a noiva resolveu ceder: "Vou fazer minha mesa de compotas, mas vou arrumar uma mesa de docinhos e colocar num canto qualquer. Vamos ver se assim as pessoas me deixam em paz".

Em trabalho anterior (Marins 2016) argumentei que os rituais matrimoniais representam, ao menos para os noivos, a ocasião em que as redes de relações sociais tecidas ao longo de suas vidas tornam-se especialmente visíveis. Com efeito, o evento que marca a celebração do casamento apresenta um potencial aglutinador particularmente acentuado, que possibilita aos noivos e às suas famílias reunirem pessoas com as quais se relacionam em contextos bastante distintos de suas vidas, que podem incluir parentes "próximos" e também os "distantes", amigos de infância, colegas de trabalho e assim por diante. Os festejos de casamento, ao mesmo tempo em que tornam visíveis e intensificam laços entre anfitriões e convidados, também manifestam conflitos e tensões. Trata-se de um ritual marcado, em certos casos, por ações religiosas, mas também por intensa comensalidade, fartura de comida e bebida e estímulos sensoriais diversos. Tal qual constatou Bitter em sua investigação sobre as folias de reis, também os ritos matrimoniais são atravessados por numerosos aspectos da realidade e são capazes de 
entrelaçar "dimensões econômicas, estéticas, morais, religiosas, materiais, 'espirituais', visíveis, invisíveis, mundanas, extramundanas" (Bitter 2008:71).

O argumento central deste artigo é que as "mesas de doces" conjugam, assim como os próprios rituais matrimoniais, estas múltiplas dimensões. Elas são atravessadas por questões estéticas, afetivas, econômicas e morais. Se observadas atentamente, as "mesas de doces" também deixam entrever a existência de uma hierarquia presente em todo o ritual, bem como uma temporalidade própria.

A centralidade das mesas de doces nos festejos que sucedem à cerimônia de casamento se deixa ver por múltiplos sinais. Ela é produto de meticulosa elaboração, ocupa lugar de destaque na decoração, além de ser atentamente observada (e entusiasmadamente visitada) pelos diversos atores que participam do evento. Os escritos de tonalidades literárias de Gilberto Freyre, para quem a doçaria do nordeste canavieiro consiste em "uma arte do doce, de uma técnica de confeitaria, de uma estética de mesa, de sobremesa e de tabuleiro tão cheia de complicações e até de sutilezas" (Freyre 2007:70), parecem se adequar à análise dos doces do casamento. Eles exibem técnica, estética, complicações e sutilezas próprias, algumas das quais serão submetidas neste artigo a exame atento. Voltando a minha atenção em especial para as funções sociais e simbólicas das mesas de doces, procuro demonstrar que o conjunto dos itens açucarados ${ }^{1}$ distribuídos aos participantes dos ritos matrimoniais condensa diversos aspectos do ritual de casamento.

Com a intenção de compreender alguns dos significados, códigos e valores que atravessam o ritual de casamento, realizei entre os anos de 2011 e 2014 trabalho de campo que redundou na minha dissertação de mestrado. Enfocando a perspectiva dos chamados cerimonialistas - profissionais que se ocupam não só, mas principalmente da organização deste tipo de evento - procurei empregar técnicas variadas de pesquisa na construção de meu material etnográfico: realizei entrevistas, li sistematicamente sites e publicações voltadas para a assim chamada "indústria do casamento", participei de diversas atividades ligadas à temática em questão, tais como cursos, workshops, palestras, feiras, encontros voltados para o mercado de casamentos. ${ }^{2}$ Também pude realizar observação direta dos rituais integrada às equipes de cerimonialistas, do momento em que eles eram montados até o seu fim. Além disso, não foi insignificante para a redação deste artigo minha participação, como convidada, em eventos que marcaram a celebração de casamentos através de minhas relações sociais.

Em diversos momentos da pesquisa a doçaria do casamento chamou minha atenção, a tal ponto que acabei por dedicar horas de observação às mesas de doces. Neste artigo, procuro sistematizar reflexões derivadas de 
tal observação e, com este intuito, tratei de dividi-lo em três seções. Na primeira, lanço um olhar de sobrevoo à trajetória dos alimentos açucarados na assim denominada "história do mundo ocidental", uma vez que, conforme assinalou Mintz, "o que aprendemos sobre comida está inserido em um corpo substantivo de materiais culturais historicamente derivados" (Mintz 2001:31). Optei por apresentar este breve histórico por acreditar que ele fornece um contexto para as reflexões mais específicas que se seguirão nas demais seções do artigo. Dedico a segunda seção a uma descrição detalhada da mesa de doces, observada em um dos rituais de casamento no qual realizei minha pesquisa de campo. Na terceira seção, que encerra este artigo, atento para o modo pelo qual os gestos e as dinâmicas de interação em torno das mesas de doces são capazes de iluminar múltiplas dimensões deste ritual.

I.

A existência e o papel de destaque dos doces em ocasiões festivas não constituem um fenômeno recente. Strong (2004), historiador interessado na história da culinária, destaca o uso ornamental do açúcar já entre os renascentistas. Os primeiros banquetes nupciais com esculturas de açúcar de que se tem notícia, segundo este autor, aparecem na Europa do século XV: diz-se, por exemplo, que no casamento de Ercole I d'Este, em 1473, elas foram carregadas em procissão, encerrando os festejos, com o propósito de "não apenas proporcionar um espetáculo, mas prestar tributo tanto aos anfitriões quanto aos convidados, numa bajulação simbólica" (Strong 2004:168). A também estudiosa da história da alimentação, Schino (2014), esclarece que, no renascentismo, o açúcar era considerado "o pináculo de todos os prazeres palatáveis" (Schino 2014:112), a "mais sublime das substâncias comestíveis" (:112). Os doces eram então ícones da aristocracia e, com preço extremamente elevado, o açúcar se tornou na Europa símbolo de riqueza e poder. Atentemos para a descrição do casamento do rei Enrico III:

Para celebrar o casamento, tudo sobre a mesa foi habilmente construído em açúcar: toalha de mesa, pratos, talheres, velas, taças [...]. Uma cenografia tridimensional foi criada, com a mesma substância, para contar a viagem de Maria de Portugal desde seu país até o Flanders. A Narratione do arquiteto particular, escrita por Francesco de Marchi, conselheiro de Margherita da Áustria, mãe do noivo, destaca a compra de três mil esculturas de açúcar por um custo exorbitante (Schino 2016:36). ${ }^{3}$ 
Não faltam registros dos suntuosos projetos feitos de açúcar erguidos por ocasião de ritos matrimoniais renascentistas. Strong (2004) menciona que no casamento de Constanzo Sforza com Camila de Aragão, em 1488, castelos de açúcar foram apresentados a embaixadores. O autor sublinha ainda que neste mesmo ano, nas núpcias de Guidobaldo da Montefeltro com Elisabetta Gonzaga, além dos castelos também foram esculpidos em açúcar "cidades, fontes, pássaros e animais, bem como dez árvores em tamanho natural" (Strong 2004:168). O açúcar podia ser servido ainda como presente aos convivas, como consta haver ocorrido nos festejos de casamento de Cosimo I, duque de Florença.

A julgar pelos registros deixados pelo mercador florentino Marco Parenti sobre o banquete de matrimônio de Lorenzo de Medici e Clarice Orsini, nos ritos matrimoniais renascentistas, a utilização ostensiva do açúcar não tinha apenas funções ornamentais, mas também gustativas. Analisando as descrições de Parenti, afirma Fallabrino (2015) que "os doces eram servidos aos convidados em abundância e variedade. Tratava-se de manjares refinados, baseados fundamentalmente em receitas que utilizavam grande quantidade de açúcar" (Fallabrino 2015:6).

Se, conforme enfatizaram Strong, Schino e Fallabrinno, ${ }^{4}$ a satisfação do desejo de doçura foi privilégio de poucos ao menos até o século XVII, a associação entre açúcar e riqueza começou a enfraquecer com a queda no preço da substância e sua consequente popularização no século XVIII. Contudo, um rastro desta ideia que associava a substância à abastança perdurava - é o que deixa transparecer a observação de Mintz (2009) ao examinar a expressão inglesa eating like a king (ou "comer como um rei"), segundo seu uso no século XVIII: “'Comer como um rei' se tornou sinônimo de beber chá, café e chocolate muito adoçados; biscoitos pela manhã e chás da tarde; eventualmente, geleia com pão comprado em lojas, doces quando desejado" (Mintz 2009:8). ${ }^{5}$

A longa história do açúcar, que pouco a pouco deixava de ser um luxo raro para se tornar produto corriqueiro, está intimamente relacionada com nossa própria história datada a partir da chegada dos portugueses ao Brasil. Por volta da terceira década do século XVI, segundo nos contam Schwarcz e Starling (2015), a administração portuguesa abria mão da política de mero povoamento da colônia para implantar aqui um projeto de monocultura do açúcar, visando ao mercado europeu, àquela altura em plena expansão.

Schwarcz e Starling sintetizam o Brasil canavieiro dos séculos XVI ao XVIII na expressão "civilização do açúcar" - capaz de evidenciar, a um só tempo, a importância econômica do comércio de doçura e também a sua extrema relevância nas esferas sociais e culturais. O açúcar é encarado pelas 
autoras como um "produtor de códigos, costumes e hábitos" (Schwarcz \& Starling 2015:50). Dentre as inúmeras implicações desse passado de produtor de açúcar, a mais notável deve estar ligada ao emprego de mão de obra escrava, que deixou marcas profundas no país, visíveis até os dias atuais. Talvez por esta razão, sejam numerosos os trabalhos sobre as condições de produção do açúcar no Brasil. Já os estudos sobre seu consumo parecem existir em menor proporção. Dentre aqueles aos quais tive acesso, encontrei registros valiosos para a compreensão do lugar ocupado pelos doces em nosso país.

O próprio trabalho de Schwarcz e Starling é revelador da importância do doce no cotidiano do Brasil colonial. Como integrante da "mesa farta", o açúcar aparece como símbolo da pujança do senhor de engenho:

nela não podia faltar o açúcar, que entrou em cheio na culinária brasileira, sobretudo no preparo de doces - de mangaba, maracujá, coco, milho, jenipapo, banana - bolos e sequilhos. Nos nomes destes quitutes estão presentes expressões sentimentais e que denotam intimidade, como "bolo de amor", "engorda marido", "namorador", "argolinhas do amor", "lacinhos do amor", ou mesmo evocações religiosas, como "pudim de Eva", "manjar do céu", "sonhos de freira" (Schwarcz \& Starling 2015:79).

Outra descrição dos doces na mesa fidalga é encontrada nos registros feitos por Maria Graham em 1820, por ocasião de um jantar no Recife com o governador Luís do Rego:

a sobremesa foi servida em outra mesa. Além de nossas sobremesas europeias de frutas, bolos e vinho, havia todos os pudins, pastelões e tortas. Estava arreada de flores e havia uma profusão de confeitos de açúcar de todas as qualidades (Graham 1956:122).

Também Gilberto Freyre chamou a atenção para a centralidade do açúcar no país, em especial na formação da identidade nacional: "O açúcar adoçou tantos aspectos da vida brasileira que não se pode separar dela a civilização nacional" (Freyre 2007:65), escreveu em sua obra dedicada à doçaria nordestina. Freyre, um dos primeiros pesquisadores interessados pelo cotidiano na colônia, sublinha ainda que, desde o século XVI, fixou-se no Brasil um gosto pelo açúcar muitas vezes considerado demasiado para o paladar estrangeiro, sobretudo o dos europeus e norte-americanos. ${ }^{6}$

Já nos trabalhos de Câmara Cascudo sobre a culinária brasileira, os doces surgem como alimentos indispensáveis na vida cotidiana, ainda que não sejam considerados "essenciais à nutrição daqueles que os consomem" (Câmara Cascudo 1968:265). Na obra deste autor a ênfase recai, 
notadamente, sobre a influência portuguesa no desenvolvimento da doçaria brasileira:

Compreende-se que essa tradição boleira e doceira em Portugal replantou-se imediata e profundamente no Brasil, servindo-se dos elementos locais, reunindo-os aos recursos trazidos da Europa, farinha de trigo, ovos, especiarias. Desde o primeiro século da colonização a doçaria portuguesa estava aclimatada e pujante em todos os centros de povoamento (Câmara Cascudo 1983:339).

A devoção dos portugueses aos bolos e doces, segundo definiu Câmara Cascudo (1983), se desenvolveria em terras brasileiras a partir da incorporação de novos ingredientes aqui encontrados. E para além da abastança da mesa de doces nacionais, outro aspecto chamou a atenção deste autor, a saber, o zelo empregado na sua apresentação:

Com a doçaria existia a não menos encantadora tradição do papel recortado, cobrindo, forrando, ornamentando os doces isolados e a bandeja, que os conduzia. Alguns são maravilhas de finura, equilíbrio e graça delicada, uma renda de intenção decorativa, de efeito surpreendente. [...] As bandejas de doces, comumente, levam panos bordados, rendas, franjas... (Câmara Cascudo 1983:338-339).

Embora eu não tenha tido acesso a uma produção historiográfica muito extensa sobre o consumo do açúcar no Brasil, os trabalhos que encontrei convergem ao considerarem o açúcar um elemento de extrema relevância no cenário culinário e cultural brasileiro. Presente no cotidiano da população e também em ocasiões extraordinárias da vida social, nossa avidez pelo açúcar parece possuir raízes longevas.

Delineei o breve compilado da história do açúcar exposto acima com o intuito de iluminar o lugar ocupado pelos doces ao longo dos séculos em ocasiões festivas e, em especial, nos ritos matrimoniais. Fosse por seu uso ornamental, por seus aspectos gustativos e nutricionais ou por sua notável capacidade de simbolizar pujança, tanto nas cortes europeias quanto nas mesas de senhores de engenho, o açúcar tem recebido a atenção de inúmeros pesquisadores. Deparei-me, no entanto, com uma escassez de registros sobre doces consumidos em ritos matrimoniais no Brasil - dificuldade encontrada também por Del Priore (2006), que alertou sobre esta lacuna na historiografia brasileira. ${ }^{7}$ Ainda assim, me sinto persuadida de que os registros sobre a trajetória do açúcar são bastante significativos para a compreensão do lugar ocupado pelos doces nos dias atuais. Voltemo-nos, pois, à mesa de doces conforme observada em um dado evento de celebração de casamento. 
II.

Numa tarde de sábado, em julho de 2013, a bilheteria do Museu de Arte Moderna do Rio de Janeiro - o MAM - acabava de encerrar suas atividades e em meia hora seria suspensa a circulação de visitantes pelas dependências do museu. A ala oeste do prédio de fachadas envidraçadas, entretanto, recebia os últimos ajustes para abrigar uma festa de casamento. Cada um dos 300 convidados que mais tarde subiriam a rampa de acesso ao segundo pavimento encontraria, na área interna, um salão com dezenas de mesas postas para jantar. Do lado de fora, de frente para os jardins de Burle Marx, um mobiliário cuidadosamente aparelhado demarcava espaços que se assemelhavam a elegantes salas de estar: havia poltronas, mesas laterais e abajures. Tapetes cobriam o piso de cimento e lustres circulares repletos de velas pendiam do pergolado. Toda a área externa fora ornamentada com árvores cenográficas dispostas em vasos de tom acobreado cuja altura individual devia ultrapassar os dois metros de altura.

Nos últimos instantes dos preparativos, havia flores por todo lado, sendo os arranjos mais elaborados da festa dispostos sobre o móvel que também abrigava os itens açucarados confeccionados para a ocasião. Como eu havia chegado ao espaço horas antes, sabia que a arrumação destas flores demandara trabalho meticuloso, realizado a quatro, seis, por vezes, oito mãos. Eu tinha podido observar enquanto tulipas vermelhas, lírios, camélias e gérberas cor-de-rosa eram cuidadosamente arranjados em vasos de porcelana de tamanhos diversos, assim como pude acompanhar a tarefa cheia de sutilezas que era distribuí-los sobre uma mesa de madeira que, segundo meus cálculos, media cerca de oito metros de comprimento por dois de largura.

Minha presença ali fora negociada semanas antes, com um dos raros cerimonialistas brasileiros que exercia a profissão havia quase três décadas. O nome de meu interlocutor era amplamente conhecido no circuito que pesquisei e era rapidamente associado a casamentos de políticos, grandes empresários e celebridades em geral. Ao ouvir sobre minha intenção de acompanhar seu trabalho de perto, o cerimonialista replicou sugerindo o evento em questão - "um casamento tranquilo", segundo ele. A respeito dos noivos e seus convidados, eu tinha poucas informações: apenas soube pelo cerimonialista que seriam muitos os estrangeiros presentes naquela noite, uma vez que o noivo era de nacionalidade francesa e soube ainda que a noiva era filha de políticos atuantes em uma pequena cidade do interior do estado.

Coincidiu mais ou menos com o fechamento das atividades do museu a entrada de meu interlocutor na área reservada aos festejos daquela noite. Àquela altura, restavam poucas pessoas no ambiente: além de sua assistente 
e eu, estava ali o dono da empresa de iluminação que havia chegado poucos minutos antes a fim de verificar se a montagem transcorrera conforme o programado. Também circulavam pelo ambiente a chefe da equipe de decoração e algumas das recepcionistas ${ }^{8}$ que trabalhariam no evento - elas seriam sete naquela noite. O cerimonialista trocou cumprimentos rápidos com os presentes e pôs-se a esquadrinhar o cenário. Ele se deteve diante da mesa de doces posicionada bem no centro do ambiente, contra uma grande parede de folhagens, e chamou a responsável pela decoração, fazendo sugestões de pequenos ajustes. Quando se deu por satisfeito com a aparência da mesa, tirou do bolso um aparelho celular e fez algumas fotos; uma delas seria publicada em certa rede social com uma legenda que, conforme eu leria mais tarde, indicava que estavam prontos os preparativos daquele evento. Os poucos profissionais que estavam presentes ao fim dos preparativos se organizavam para partir em direção ao centro da cidade, onde estava localizada a igreja na qual ocorreria a celebração religiosa do casamento.

Aproveitei os minutos que precediam também o meu deslocamento até a igreja para me aproximar da mesa de doces e examiná-la mais detalhadamente. Sobre o móvel, além de cuidadosamente aparelhado com uma variedade de arranjos florais, eram exibidos dois grandes castiçais de cristal que, juntos, serviam de suporte a uma dezena de velas. No centro da mesa estava o "bolo de casamento", 9 que de fato consistia em quatro bolos redondos de tamanhos distintos, cobertos com pasta americana branca, sobrepostos, sendo o maior bolo na base e o menor no topo. Sobre o último andar havia um confeito de açúcar em forma de flores. Havia também fartura do doce típico conhecido como "bem-casado" - dois pequenos pedaços redondos de pão de ló unidos por um creme adocicado - que ali estavam embrulhados em papel de seda, nas cores verde e branca, e arrematados com laços de cetim. Ora acondicionados em bandejas sobrepostas, ora em travessas de prata ou em bombonières de cristal, havia um sem-número dos chamados "doces finos", ${ }^{10}$ fondados e caramelizados, todos eles delicadamente apresentados dentro de forminhas de tecido em feitio de pétalas. Também notei algumas variedades de chocolates trufados e de doces típicos portugueses "barrigas de freira", arrumados com esmero sobre salvas de prata.

Com a chegada dos convivas ao salão e a inauguração da festa de casamento, observei que a atenção sobre a mesa de doces por parte dos presentes passou a se dar de maneira flutuante. Num primeiro momento, notei alguns convidados - mulheres, em sua maior parte - efetuando uma primeira incursão à mesa com a finalidade primordial de observá-la. Aproximando-me das pessoas que passeavam pelas imediações da mesa, ouvi comentários a respeito da beleza e da variedade dos itens açucarados ali dis- 
postos e também observei que alguns convidados os fotografavam utilizando câmeras amadoras. A esta altura, aliás, também um fotógrafo profissional se aproximou da mesa, tratando de capturar imagens dos doces a partir de diversos ângulos. Assim que os noivos chegaram ao espaço da festa, a mesa de doces voltou a adquirir protagonismo, em especial durante as ações rituais conhecidas como "brinde" e o "corte simbólico do bolo": reunidos em torno da mesa com os respectivos parentes e padrinhos, os noivos receberam de um garçom taças de vinho espumante e fizeram um brinde diante das lentes de câmeras fotográficas e de vídeo. Quando o fotógrafo indicou que seus registros já estavam feitos, o casal, com as mãos unidas, segurou a espátula efetuando um pequeno corte no bolo, que seria consumido ao final da festa.

Durante o período em que foi servido o jantar, a circulação em torno da mesa de doces diminuiu sensivelmente. Mas ainda que os convidados não se aproximassem do móvel na maior parte do tempo, uma funcionária da equipe de recepcionistas permaneceu ao lado da mesa de doces, do início ao fim da festa. Uma vez que minha admissão naquele evento fora precedida de uma entrevista formal com o cerimonialista responsável pela festa, eu já conhecia as funções exercidas pelos integrantes de sua equipe. No caso da "vigilante" da mesa de doces, sua atribuição principal era cuidar para que a mesa preservasse sua aparência incólume, devendo assim descartar forminhas dos doces que tivessem sido consumidos e remover objetos eventualmente abandonados sobre a mesa ao longo da festa, tais como copos ou guardanapos. Além disso, num esforço de manter a oferta de doces permanentemente farta, a "vigilante" deveria repor os docinhos conforme eles fossem dali subtraídos. ${ }^{11}$

O consumo dos doces antes do encerramento do jantar, contudo, fora realizado com certa parcimônia, a julgar pelos gestos discretos daqueles que retiravam da mesa um docinho nas primeiras horas da festa. As visitas à mesa de doces se intensificaram, de fato, ao fim da refeição principal, momento em que o móvel foi cercado pelos convidados. Os quitutes passaram a ser então consumidos com avidez e alguns foram acidentalmente derrubados no chão. Um ou outro convidado visitava a mesa munido de pratinhos ou guardanapos a fim de se servir de múltiplos doces de uma só vez. O armazenamento de doces com o intuito de consumi-los após a festa não era de todo incomum: em dado momento, por exemplo, testemunhei, sob o olhar chocado de outro convidado, uma senhora utilizar a sacola de pano ofertada pelos noivos como invólucro dos chinelos distribuídos na pista de dança para atarracar ali uma quantidade de doces que devia alcançar duas dezenas.

O entusiasmo em torno da mesa de doces foi se dissipando à medida que a festa se aproximava do fim. As fatias de bolo servidas pelos garçons 
eram deixadas parcialmente sobre o prato - o que, a mim, parecia indicar um certo empanzinamento geral. A mesa de doces, que fora cuidadosamente refeita ao longo das horas da festa, permanecia vistosa.

III.

Provavelmente um dos aspectos mais sensíveis ao observador da mesa de doces, exibida por ocasião dos ritos matrimoniais, diz respeito à ideia de fartura. Ao longo dos preparativos e também dos festejos que acompanhei na condição de pesquisadora ou a partir de minhas relações sociais, observei uma preocupação constante com a fartura dos doces. ${ }^{12}$ Com efeito, "faltar doces" (assim como faltar comida, bebida ou animação) parecia configurar um importante temor dos anfitriões que, por sua vez, manifestavam a percepção de que organizar um evento de celebração de casamento os deixaria sujeitos a comentários desabonadores.

Também a dimensão estética das mesas de doces, considerada de crucial importância para os atores que gravitam em torno dela, se entrelaçava à ideia de fartura. Uma mesa vistosa era necessariamente aquela que parecia farta. O delicado e minucioso trabalho de dispor os doces sobre a mesa era realizado de modo a atender a estes dois requisitos básicos. Com o intuito de montar algo que fosse considerado belo, os decoradores responsáveis pelo trabalho lançavam mão de alguns recursos que ajudariam a conferir à mesa uma impressão de abundância: forminhas de doces volumosas e arranjos de flores copiosos pareciam cumprir esta função. Conforme busquei demonstrar, o móvel sobre o qual são dispostos os doces de casamento também abrigava outros objetos cuja função primordial é a de ornamentação. Os próprios docinhos, aliás, eram delicadamente enfeitados com flores e laços. E se o excedente e a beleza da mesa de doces constituíam importantes critérios para a sua avaliação, os anfitriões demonstravam também considerável preocupação com a qualidade das guloseimas - e isto fica particularmente evidenciado no processo de aquisição dos doces.

Se, por um lado, a necessidade de ofertar doces que, além de fartos e bonitos, fossem saborosos não parecia ser algo secundário nos discursos de meus interlocutores, por outro lado, eu permanecia com a impressão de que servir "doces gostosos" não era exatamente feito difícil de se cumprir. Ao contrário, nas múltiplas ocasiões em que testemunhei o consumo de doces nas festas de casamento, me pareceu que a doçaria despertava, na maior parte das vezes, imenso prazer. Foram raras as situações nas quais ouvi alguém reclamar do sabor de docinhos e, mesmo assim, quando isso acontecia, o 
desagrado parecia dizer respeito a um tipo de doce em particular, e não à variedade ofertada. Era como se a predominância do gosto doce, por si só, desse conta de agradar o paladar dos convivas que frequentavam a mesa.

Em artigo no qual examina o consumo de itens de confeitaria entre os britânicos, James (1990) se indagava a respeito de um aumento substancial de itens de confeitaria, a despeito da condenação por parte dos profissionais de saúde de substâncias que combinam açúcar e gordura. Os "perigos do açúcar", tema àquela altura constantemente midiatizado, não parecia surtir efeito sobre as escolhas alimentares dos britânicos - e isto justamente em um momento em que o conceito de "comida saudável" parecia ganhar uma força até então sem precedentes. A resposta para tal impasse, conforme argumenta James, reside nos aspectos simbólicos desempenhados pelos itens de confeitaria no Reino Unido. A análise realizada por James a respeito de tais itens, que incluem chocolates, bolos e tortas, biscoitos e cremes, é rica e cheia de nuances. A confeitaria é considerada substância ambígua. Segundo o sistema classificatório inglês evocado por James - que é também verificado entre nós - doces não são considerados "comida de verdade". Como substância ambígua, os doces, assinala James, condensam uma variedade de significados sociais. Doces fazem as vezes de presentes, podem ser ofertados junto com um pedido de desculpas, como demonstração de gratidão. Os doces simbolizam deleite, um presente para o outro ou para si mesmo. A confeitaria tem o poder simbólico de mediar relações sociais, é um "registro simbólico de afeição" (James 1990:678). O mesmo poder do doce de mediar relações sociais, aliás, foi sublinhado por Câmara Cascudo (1983), como herança dos portugueses que ganhou importância na mesa do brasileiro:

O bolo possuía uma função social indispensável na vida portuguesa. Representava a solidariedade humana. Os inumeráveis tipos figuravam no noivado, casamento (o bolo de noiva), visita de parida, aniversários, convalescença, enfermidades, condolências. Era a saudação mais profunda, significativa, insubstituível. Oferta, lembrança, prêmio, homenagem traduziam-se pela bandeja de doces. [...] O doce visitava, fazia amizades, carpia, festejava. Não podia haver outra delegação mais legítima na plenitude simbólica da doçura. Completava a liturgia sagrada e o cerimonial soberano (Câmara Cascudo 1983:333).

Outro aspecto do trabalho de James que pode nos auxiliar na compreensão do papel exercido pela mesa de doces nos ritos matrimoniais diz respeito a associações linguísticas ao termo doce. Inspirada nesta ideia, fiz uma rápida revisão de expressões em língua portuguesa que contêm a palavra doce ou termos correlatos. O doce então apareceu como forma carinhosa de tratamento ("um doce de pessoa", "meu doce de coco", "docinho"); em 
algumas expressões, tais como "mel na chupeta e "mamão com açúcar", o doce parece imprimir uma ideia de facilidade, e há ainda as expressões nas quais alimentos doces parecem simplesmente designar algo bom, desejável (ex.: "acabou-se o que era doce", "manjar dos deuses", "quem nunca comeu melado, quando come se lambuza"). De semelhante modo, "tratar alguém a pão de ló" significa tratar alguém muito bem, com capricho e atenção. Adicionalmente, busquei o verbete "doçura" em um dicionário da língua portuguesa e o resultado reproduzo a seguir:

(do.çu.ra)

sf.

1. Característica do que é doce; DULÇOR: a doçura do açúcar. [ Antôn.: acidez, amargor, azedume.]

2. O gosto de algo doce

3. Fig. Qualidade de quem é meigo, terno; MEIGUICE; TERNURA

4. Fig. Suavidade, brandura

5. Fig. O que é agradável, prazeroso; DELEITE; DELÍCIA: a doçura de um sorriso infantil

(DOÇURA. In: Dicionário Aulete Digital. Disponível em: < http://www.aulete. com.br/do\%C3\%A7ura >. Acesso em 16/06/2016).

Com base neste breve exame das acepções de doce encontradas na língua portuguesa, suponho que no contexto de minha pesquisa, assim como naquele investigado por James, as associações linguísticas entre doçura e prazer, deleite e desejabilidade reforçam e são reforçadas pelo uso social da doçaria como presente ou afago. Os doces de casamento, neste sentido, fazem as vezes de dádivas ofertadas pelos anfitriões aos convidados. Alimentar-se de doces neste ritual é, portanto, um ato social por excelência, "é o momento de reforçar a coesão do grupo pois, ao partilharem a comida, partilham sensações, tornando-se uma experiência sensorial compartilhada" (Maciel 2001:145). Mais do que isso, os itens de doçaria parecem preservar forte potencial de nutrir laços emocionais.

Não me parece fruto do acaso que mesas de doces semelhantes àquelas das festas de casamento ocupem também lugar de centralidade em outras comemorações familiares brasileiras. ${ }^{13}$ Se oferecer e receber alimentos constituem maneiras encontradas pelo homem de estabelecer e preservar vínculos entre si, os doces de casamento, repletos de significados, guardam relação com aqueles observados em outros ritos de passagem. ${ }^{14}$

Por outro lado, os doces servidos nos festejos matrimoniais também possuem particularidades que julgo serem merecedoras de atenção, pois a mesa de doces das festas de casamento é, por excelência, lugar dos assim 
denominados doces finos (em oposição aos doces "populares"). Nos eventos que marcam os ritos matrimoniais, em geral, não costuma haver lugar para doces típicos brasileiros, tais como pés de moleque, goiabada, marmelada, cocada. Antes, as mesas dos casamentos exibem doces considerados mais sofisticados: bem-casados, barrigas de feiras, camafeus de nozes, doces fondados. Doces típicos de festas de aniversário, como brigadeiros e beijinhos

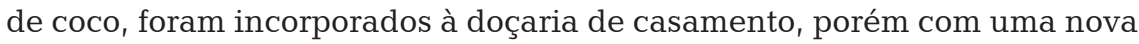
roupagem que os caracteriza como tal.

Chegamos, portanto, a outro aspecto evocado pela análise das mesas doces que, na minha opinião, é bastante significativo para a compreensão dos ritos matrimoniais que venho investigando. Refiro-me, no caso, ao pronunciado caráter de elemento de distinção social nos moldes do mais célebre trabalho de Bourdieu (2015).

Tal qual procurei demonstrar neste artigo, o açúcar foi substância bastante presente em banquetes, em especial ao longo dos séculos XV e XVI na Europa. Sua importância em ocasiões festivas parecia se associar não apenas aos seus aspectos estéticos e gustativos, mas também ao seu alto preço - que à época restringia a exibição de itens açucarados à nobreza. Tratando deste tema, Mintz (2009) ressalta que a difusão do açúcar ocorrida a partir do século XIX tornou a substância mais barata e, portanto, fez ruir sua outrora magnífica importância simbólica como ícone de prosperidade, bem-estar e poder. Embora não seja minha intenção contestar a proposição de Mintz - proposição esta que, diga-se de passagem, parece-me bastante sólida - gostaria de enfatizar seu caráter circunstancial. Mesmo sendo o açúcar uma substância bastante barata e corriqueira, no contexto que pesquisei, os itens açucarados parecem de fato operar como marcadores de "classe". Alguns dos indícios para tal constatação estão presentes em aspectos que procurei expor até aqui: a constante preocupação com a fartura e o cuidado excepcional em reunir na mesa de doces objetos decorativos e itens de confeitaria considerados nobres apontam que a mesa de doces é investida, ela mesma, de forte senso de distinção.

Contudo, gostaria de chamar a atenção para um aspecto que julgo particularmente revelador de tal dimensão. Refiro-me à noção de "bom-gosto", muito recorrente (quase onipresente, eu diria) nos discursos de meus interlocutores. O gosto aparece aqui como um sistema de classificações hierarquizante. Segundo este sistema, o doce conhecido como cajuzinho ocupa posição inferior ao bem-casado, assim como o bolo de cenoura coberto por chocolate é devedor do bolo recheado com nozes e damasco em termos de "bom-gosto", de acordo com o esquema de classificação nativo. ${ }^{15}$ "Bom gosto", aqui, supera as questões relacionadas às qualidades gustativas da 
doçaria de casamento. Os docinhos, suas embalagens, os arranjos florais que os ladeiam, bem como os demais objetos dispostos sobre a mesa - e o próprio móvel - são também portadores de mensagens acerca de pertencimentos sociais.

Em artigo dedicado ao buquê da noiva, Cavalcanti (2007) sugere que este objeto especial é "a expressão concreta da própria noiva" (Cavalcanti 2007:63). Eu defenderia que o mesmo se aplica ao objeto que ora analiso, desde que feito um pequeno adendo: a mesa de doces é a expressão concreta do grupo diretamente envolvido no casamento - ou seja, arquetipicamente, a noiva e também o noivo e seus respectivos pais. A dinâmica em torno das mesas de doces durante os festejos do casamento, bem como as questões envolvidas em seus preparativos parecem deixar claro que os ritos matrimoniais são capazes de pôr em jogo o nome e a reputação de seus participantes, em especial dos anfitriões.

Cabe-me aqui assinalar, entretanto, que a reputação dos anfitriões não é a única em xeque nos ritos matrimoniais. Neste sentido, a observação da mesa de doces nos permite constatar que também os convidados são avaliados por seu comportamento nesses eventos.

Na seção anterior procurei descrever o movimento em torno das mesas de doces nos primeiros momentos da festa, quando os convidados - em especial as convidadas - visitavam a mesa sem, no entanto, tocá-la. Após observar a repetição desta dinâmica em diversos eventos, passei a encará-la como um rito. Creio poder afirmar que este rito põe em jogo, primeiro, o reconhecimento por parte dos convidados do esmero, da boa vontade, do "bom gosto" empregados no esforço de exibir uma mesa farta e vistosa. Além disso, interpreto as primeiras visitas a ela como uma espécie demonstração de autocontrole própria do processo civilizador problematizado por Elias (1993, 1994).

O estado da mesa de doces revela uma temporalidade própria do casamento. Segundo me explicou certa vez uma interlocutora, a distribuição do bolo e o consumo ostensivo dos doces marcam o início do fim dos festejos. Tomando a mesa de doces como divisora destes dois momentos, diria que, na primeira etapa dos festejos de casamento, os doces são vistos, admirados, cobiçados, eventualmente roubados. No segundo momento, são ingeridos, degustados, por vezes, atacados. O comportamento dos convidados diante da mesa de doces pode ser encarado como prova de civilidade. Trabalhando junto às equipes de cerimonialistas, pude notar que o modo com que as pessoas se relacionavam com os docinhos era, recorrentemente, assunto dos profissionais nos bastidores. ${ }^{16}$ Sobretudo quando a doçaria era consumida com voracidade, ouvia murmúrios que mesclavam divertimento e reprovação: 
"Parece que nunca viram doces na vida!", ou "Veja só os mortos de fome...", "Essa gente não sabe se portar". Diante da mesa de doces depenada ou atacada, a civilidade surge como um valor desejável para o grupo. "Saber se portar", assim, se opõe ao comportamento do "morto de fome".

Ali, as atitudes dos convidados são constantemente avaliadas, não apenas pelo cerimonial, mas também pelos outros convidados da festa. O comportamento social considerado aceitável parece excluir o "roubo" de doces na primeira etapa da festa, bem como a voracidade no consumo. Contudo, a etiqueta que rege a ingestão de doces no casamento pode ser desconsiderada em certas circunstâncias. E isto nos leva a mais uma característica dos rituais matrimonias que a mesa de doces nos permite entrever - a fim de abordá-la, permito-me descrever brevemente duas situações que vivi durante o trabalho de campo.

Em meados de 2013, eu buscava olhar para os eventos de celebração de casamento pela perspectiva dos cerimonialistas e, com o intuito de melhor perceber as nuances de seu trabalho, havia negociado minha participação em alguns rituais na condição de assistente destes profissionais (posto também denominado de recepcionista). Certa vez, trabalhando como uma das recepcionistas que integravam a equipe do cerimonial, me foi atribuída a tarefa de "ficar de olho na mesa de doces". Na ocasião, fui instruída pela cerimonialista a não permitir que as pessoas pegassem doces antes que tivesse terminado o serviço do jantar. Algo constrangida com a tarefa a mim designada e temerosa de falhar em cumpri-la, solicitei à cerimonialista maiores explicações sobre a maneira de abordar os convidados, ao que minha interlocutora respondeu: "Aproxime-se da pessoa que estiver roubando doces, fale em voz baixa e calmamente, sorrindo de preferência. Avise para ela que a noiva pediu para que os doces só fossem servidos depois do jantar. Quando a gente fala que é pedido da noiva, as pessoas obedecem, você vai ver".

Alguns meses mais tarde fui colocada em posição similar, desta vez tomando conta dos bem-casados. A etiqueta que rege o consumo destes doces é diferente daquela que se aplica aos chamados docinhos finos, e uma recepcionista experiente teve o cuidado de me explicar que eu deveria entregar um bem-casado por pessoa e somente na hora em que ela estivesse deixando a festa. À medida que as horas iam passando, mais e mais pessoas subtraíam os doces dos montinhos cuidadosamente arrumados sobre uma estante e eu me sentia incapaz de impedi-las. A cada vez que minha supervisora flagrava alguém desembrulhando um bem-casado "fora de hora", eu era discretamente repreendida. A certa altura, uma senhora se aproximou do móvel e, sem exibir qualquer sinal de pudor, apanhou quantos bem-casados conseguiu carregar. Os bolinhos eram equilibrados sobre a parte interna de 
seu antebraço esquerdo que, colado ao corpo, deve ter servido de suporte para mais de dezena de doces. Observando a cena do outro lado do salão, minha supervisora gesticulava para que eu impedisse a ofensiva, mas optei por ignorá-la. Segundos mais tarde, em resposta a uma reprimenda, pude explicar meus motivos: eu tinha notado que a "assaltante de bem-casados" era a mãe da noiva. Diante do exposto, não apenas fui livrada da censura, como também recebi um efusivo agradecimento. Suspirando com uma das mãos sobre o peito, minha interlocutora explicou que, caso eu tivesse abordado a mãe da noiva, eu teria cometido "a maior das gafes".

Em trabalho no qual focaliza os usos sociais e culturais do alimento, Douglas (1984) propõe que a comida seja tratada como um código que, decodificado, é capaz de revelar graus de hierarquia, inclusão e exclusão, fronteiras e negociações. O que os dois breves relatos revelam, a meu ver, é uma hierarquia dos atores que participam dos ritos matrimoniais. A noiva parece ocupar o mais alto posto: é dela a autoridade sobre os doces e espera-se que os convidados saibam disso. Cabe mencionar, aliás, que não me recordo de ter visto a noiva se aproximar da mesa de doces a fim de consumi-los. Já testemunhei, por outro lado, situações nas quais os cerimonialistas providenciaram para que uma caixa de doces fosse encaminhada à noiva. Por vezes, algo semelhante se passava com as madrinhas que, logo após a celebração do casamento, recebiam da noiva uma pequena caixa decorada contendo uma variedade de docinhos - nestes casos, as madrinhas tinham a prerrogativa de levar os doces para casa. Além da noiva, também o noivo e seus pais parecem ter acesso irrestrito à doçaria, embora mais uma vez eu deva ressaltar que a presença de homens em torno da mesa de doces é minoritária. O tratamento diferenciado aos participantes do evento constitui, assim, indicativo de que determinadas hierarquias vigoram nos ritos matrimoniais.

Por seu caráter multivocal e polifônico, por sua simbologia positiva e também por sua capacidade de engendrar e expressar tensionamentos, parece-me oportuno pensar nos doces de casamento à luz da teoria turneriana a respeito das propriedades dos símbolos rituais (Turner 2005:58). Destarte, enfatizo sua propriedade de condensação - uma vez que, conforme procuro demonstrar neste artigo, o símbolo ritual que aqui analiso sobrepõe diversos níveis de sentido - e também a propriedade de polarização, posto que eles dizem respeito, a um só tempo, a polos de sentidos claramente distinguíveis, ora da ordem moral e social, ora da ordem sensorial.

Finalmente, gostaria de chamar a atenção para um último aspecto revelado pela observação da mesa de doces, pois me parece que esta pode servir de primorosa ilustração do continuum dos eventos de celebração de casa- 
mento que partem da solenidade formal em direção à informalidade festiva.

Em trabalho anterior (2016) procurei demonstrar que a etapa inicial dos rituais de casamento observados, notadamente aquela denominada "cerimônia de casamento", era marcada por considerável dose de formalidade. Durante a cerimônia de casamento, fosse ela religiosa ou não, havia uma sequência de ações a serem cumpridas, por exemplo, a caminhada ritual da noiva, a troca de alianças, os votos e a afirmação pública de que casar-se é um ato efetuado "por livre e espontânea vontade", que sinalizavam uma espécie de austeridade vigente nesta etapa ritual.

Foi observada a existência de um momento ritual, quando a cerimônia era concluída para que se iniciassem os festejos, em que tal formalidade era suavizada, porém certamente não anulada. Nesse momento intermediário, desenrolava ainda uma série de ações rituais previstas no protocolo (tais como o corte do bolo, a dança dos noivos e o brinde dos pais), que pareciam ser executadas com menor rigidez.

O momento da "liberação da mesa de doces" era também aquele em que os festejos eram tomados por uma dimensão de antiestrutura, para utilizar o conceito de Turner (2013). Trata-se de uma etapa do ritual na qual prevalecia a espontaneidade, opondo-se à formalidade que marcava as etapas anteriores. Se nos momentos iniciais das festas perdurava uma atmosfera notavelmente controlada (à semelhança daquela observada nas cerimônias de casamento), nos momentos finais verificava-se uma importante redução do regramento. Era comum, a esta altura, que a pista de dança se tornasse o centro da festa, onde os protagonistas do ritual (os noivos e seus pais) dançavam lado a lado com os convidados. A música era tocada em alto volume e o seu estilo costumava ser bastante distinto daquele preponderante no início do evento. As mulheres deixavam seus pés descalços ou trocavam suas elegantes, porém desconfortáveis, sandálias de salto alto por chinelos disponibilizados pelos anfitriões. No salão, paletós repousavam sobre os espaldares das cadeiras e os homens circulavam de gravatas afrouxadas. Possivelmente sob o efeito do álcool (mas não necessariamente), convidados e anfitriões pareciam se entregar a experiências de ordem sensorial: a fruição da música se tornava visível na dança de gestos exagerados e os comensais se refestelavam na mesa de doces.

Se do ponto de vista teórico a análise dos ritos matrimoniais certamente pode se valer dos trabalhos de Turner, talvez seja o caso de evocar aqui o conceito de communitas deste mesmo autor "como um lugar de despojamento e de compartilhamento de aspectos universais da experiência humana" (2013:105), conforme chamou a atenção Cavalcanti (2012). Com efeito, após ter observado diversas vezes esta etapa final dos eventos de celebração de 
casamento, tive a recorrente sensação de presenciar um fenômeno de acordo com a explanação de communitas apresentada por DaMatta: "de uma forte e singular (para não dizer, anômala) coletivização [...] um estado destituído de individualidade e compartimentalização" (DaMatta 2000:15-16).

Tenhamos em mente que a communitas, segundo esclarece o próprio Turner, "em pouco tempo se transforma em estrutura" (Turner 2013:128), passando então a organizar um sistema social duradouro. E se, como diz este autor (2005), o modelo básico da sociedade consiste numa estrutura de posições, que é também dotada de um certo grau de dinamismo, o ritual de casamento (do qual faz parte a mesa de doces) é capaz não só de conferir visibilidade a esta estrutura, como também de produzir efeitos sobre as posições dos atores sociais nesta mesma estrutura.

\section{Considerações finais}

Durante a realização da pesquisa de campo que deu origem a este artigo, instigada pela importância simbólica que as mesas de doces pareciam transparecer, em poucas ocasiões tentei encorajar meus interlocutores a discorrerem sobre elas. Tal como no relato que dá início a este artigo, diversas vezes me deparei com situações nas quais os noivos relegavam os doces às posições mais baixas da hierarquia dos itens de consumo do casamento. Ao notar que recebia, sistematicamente, respostas breves e pouco entusiasmadas a respeito dos doces, optei por abandonar este intento. Com efeito, a falta de eloquência dos meus interlocutores diante do tema parecia revelar certa desproporção entre ação e discurso. Se, por um lado, eu constatava, a partir da conduta de meus interlocutores, que as mesas de doces eram objeto de grande atenção, por outro, quando inquiridos a respeito, eles sinalizavam que os doces servidos nos casamentos nada mais eram do que uma espécie de pormenor em meio a tantos outros elementos supostamente mais significantes.

Este trabalho consiste, portanto, em um esforço de dedicar atenção a algo que meus nativos reiteradamente sinalizavam, através de ações, como socialmente relevante, embora pouquíssimas vezes verbalizassem tal importância. À medida que eu avançava na análise das mesas de doces, mais evidente se mostrava sua centralidade nos rituais matrimoniais. Mais do que isso, por seu conteúdo simbólico, os doces servidos nos eventos de celebração de casamento pareciam sintetizar aspectos fundamentais dos rituais. Um deles, implícito ao longo do texto, diz respeito a espaço e tempo - categorias de pensamento que, como tais, encarnam valores socialmente construídos. 
Argumento, neste sentido, que refletir sobre os rituais matrimoniais analiticamente a partir da oposição entre estrutura e antiestrutura, conforme propus na seção anterior, implica pensar em espaço e tempo. Primeiro, porque a mesa de doces nos festejos de casamento demarca um espaço físico onde o regramento característico da dimensão estrutural permanece visível durante quase toda a duração dos festejos. A mesa delimita a área da festa que deve ser preservada intacta para os registros fotográficos, sendo assim interditada aos convidados - um indício de tal fato reside, por exemplo, na presença permanente de um funcionário nas proximidades da mesa de doces com o intuito de vigiá-la. Em segundo lugar, a mesa de doces opera como um demarcador temporal da festa, uma vez que a própria comestibilidade dos itens açucarados está condicionada ao tempo do ritual. Como procurei demonstrar ao longo deste artigo, a interação e os gestos em torno dos "doces de casamento" são capazes de sinalizar as diversas etapas do complexo ritual.

Finalmente, sem pretender esgotar as inúmeras possibilidades analíticas apresentadas pela mesa de doce, chamo a atenção para o potencial destes itens em ampliar fronteiras temporais e mesmo espaciais dos ritos matrimoniais. É o que ocorre com o consumo dos bem-casados, entregues aos convidados e que, tradicionalmente, são consumidos por eles no dia seguinte e em suas residências. Diz-se, aliás, que congelar um pedaço do bolo de casamento para consumi-lo um ano após a data da celebração é capaz de trazer boa-sorte aos noivos. Neste sentido, os doces nos permitem desconstruir uma ideia, bastante presente no senso comum, de que o casamento é um ritual que "dura apenas algumas horas".

Recebido em 07 de outubro de 2016

Aprovado em 10 de julho de 2017

Cristina Teixeira Marins é doutoranda no Programa de Pós-Graduação em Antropologia, Instituto de Ciências Humanas e Filosofia, Universidade Federal Fluminense, Niterói, RJ, Brasil. E-mail: <ctmarins@gmail.com> 


\section{Notas}

* Versões preliminares deste artigo foram apresentadas a pesquisadores que contribuíram com comentários valiosos. Neste sentido, agradeço aos integrantes do grupo de pesquisa liderado pelo professor Edilson Márcio Almeida da Silva pelas críticas e sugestões. Agradeço também à professora Lucía Eilbaum pelo constante estímulo. Igualmente importante tem sido o apoio de Marta Patallo e Izabel Nuñez. Agradeço ainda aos pareceristas anônimos pelas leituras atentas e comentários generosos. A pesquisa que deu origem a este artigo contou com o apoio financeiro da CAPES.

1 Cabe aqui fazer uma distinção entre os doces de casamento e a sobremesa servida no casamento. A sobremesa é tratada como parte do menu do casamento e não costuma ser cercada de cuidados como o bolo e os docinhos. Estes últimos compõem a "mesa de doces" que, conforme depreendi do discurso de meus interlocutores, é uma expressão que designa o conjunto composto pelo móvel (ou móveis, em alguns casos) e pelos doces considerados típicos de casamento e também pelo bolo de casamento.

2 Embora durante a realização de minha pesquisa de mestrado eu não tenha tido acesso a trabalhos que tratem do mercado de casamentos no contexto nacional, recentemente tenho notado um interesse crescente pelo tema. Neste sentido, cito os trabalhos de Escoura (2016) e Meneses (2017).

3 Traduzi do original: "Per celebrare le nozze, ogni cosa sulla tavola fu realizzata abilmente in zucchero: tovaglia, piatti, posate, candele, calici [...] . Fu realizzata una scenografia tridimensionale, creata nella stessa sostanza, per raccontare il viaggio di Maria dal Portogallo dal su Paese verso le Fiandre. La Narratione particolare dell'architectto militare, scritta da Francesco de Marchi, consigliere di Margherita d'Austria, madre dello sposo, evidenzia l'acquisto di tremila sculture in zucchero per un costo esorbitante" (Schino 2016:36).

4 Sobre este tema, ver também Braudel (2005).

5 Traduzido do original: "'Eating like a king' had come to mean drinking heavilysweetened tea, coffee and chocolate; biscuits at morning and afternoon teas; eventually, marmalade with store-purchased bread, pastries when desired" (Mintz 2009:8) Mintz faz menção ainda à virada do século XIX para o XX, quando "comer como um rei" se traduzia também em consumir os doces manufaturados pelos fabricantes Cadbury, Fry e Rowntree e os bolos de casamentos, estudados por Charsley (1992).

6 Sobre a censura ao gosto pelo açúcar entre os brasileiros, ver também Câmara Cascudo (1968).

7 Curiosamente, a única menção ao consumo de doces em casamentos que encontrei tratava do casamento de escravos, nos festejos então denominados "funções". Segundo Del Priori: "A função era uma festa ao som de batuques, violas e atabaques em que se comia rapadura e havia distribuição de cachaça. Alguns escravos endividavam-se com seus senhores para poder oferecer uma festa pelo casamento de seus filhos. Depois teriam de trabalhar dobrado para pagar a dívida" (Del Priore 2013:25). 
8 "Recepcionistas" ou "assistentes do cerimonial" são termos que designam os integrantes da equipe dos cerimonialistas.

9 Devo esclarecer que não pretendo dedicar atenção especial ao bolo de casamento, embora este emblemático item seja, certamente, rentável em termos analíticos. Não por acaso, os bolos de casamento já foram objeto de reflexão antropológica de Wilson (1972) e Charsley (1992). O bolo será, para fins analíticos, considerado como parte da mesa de doces.

10 Não só em minhas participações nos eventos, mas principalmente nas ocasiões da pesquisa em que eu observava os preparativos do casamento, ouvi referências aos "doces finos" - estes geralmente distinguidos dos doces consumidos no cotidiano ou mesmo em outras festas pelo seu difícil e delicado preparo.

11 Posto que minha presença naquele evento se sucedia a outras participações em ritos matrimoniais - ora como convidada, ora como pesquisadora - cabe aqui ponderar sobre o papel exercido pelo "vigilante" nas imediações da mesa. Em alguns casos, sua presença tinha como principal objetivo impedir o consumo dos doces antes do momento considerado adequado, isto é, após o encerramento da refeição principal.

12 Esta produção de excedentes, aliás, talvez seja a principal razão pela qual boa parte de meus interlocutores descrevia os preparativos como um processo desgastante, "estressante" e mesmo "sofrido". Todo o trabalho empregado na organização de um casamento, por um lado, deveria necessariamente produzir um excedente, porém, na outra ponta, os anfitriões precisavam lidar com a limitação de recursos disponíveis para este fim.

13 Em sua investigação sobre práticas e saberes alimentares de imigrantes brasileiros na Grande Boston, Assunção (2011) constata que a doçaria consumida em eventos familiares constitui ainda um "importante vetor de reprodução social e identitária entre os imigrantes" (Assunção 2011:222). Deste trabalho, destaco uma passagem que considero particularmente reveladora do conteúdo afetivo dos doces, na qual uma das interlocutoras relata ter recebido "docinhos de festa de sua irmã brigadeiro, beijinho, cajuzinho, entre outros - pelo correio, dentro de uma caixa de ovos" (:222).

14 Refiro-me aqui à noção cunhada por Van Gennep (2011).

15 Não que as posições dentro deste esquema sejam rígidas e aplicáveis a todos os atores do universo que pesquiso. Em trabalho anterior (Marins 2016) procurei demonstrar que, em certos casos, tais esquemas classificatórios são deliberadamente subvertidos. Porém, em termos gerais, anfitriões e outros atores que participam da dinâmica das mesas de doces (notadamente os profissionais que atuam nos eventos e os convidados) demonstram conhecer o esquema e orientar-se por ele.

16 Cabe apontar, entretanto, que o "roubo" de docinhos era recorrente também entre os profissionais que integravam a equipe de cerimonial do evento. A particularidade que se aplicava a tais casos é que o consumo dos doces, conforme pude observar, se dava longe dos olhos dos noivos ou dos demais convidados da festa. 


\section{Referências bibliográficas}

ASSUNÇÃO, Viviane Kraieski de. 2011. Onde a comida "não tem gosto": estudo antropológico das práticas alimentares de imigrantes brasileiros em Boston. Tese de Doutorado em Antropologia Social, Centro de Filosofia e Ciências Humanas, Universidade Federal de Santa Catarina, Florianópolis, SC. Disponível em: http://repositorio.ufsc. br/xmlui/handle/123456789/95311. Acesso em 07/10/2016.

BITTER, Daniel. 2008. A bandeira e a máscara: estudo sobre a circulação de objetos rituais nas folias de reis. Tese de Doutorado em Antropologia, Rio de Janeiro, UFRJ, IFCS, PPGSA. Disponível em: http://portal.iphan. gov.br/uploads/ckfinder/arquivos/A bandeira e a máscara.pdf. Acesso em 07/10/2016.

BOURDIEU, Pierre. 2015. A distinção: crítica social do julgamento. $2^{\mathrm{a}}$. ed. Porto Alegre: Zouk.

BRAUDEL, Fernand. 2005. Civilização material, economia e capitalismo, séculos XV-XVIII. Vol.1: As estruturas do cotidiano. São Paulo: Martins Fontes.

CÂMARA CASCUDO, Luís da. 1968. História da alimentação no Brasil - segundo volume. São Paulo: Companhia Editora Nacional. . 1983. História da alimentação no Brasil - primeiro volume. Belo Horizonte: Ed. Itatiaia/ São Paulo: Ed. da Universidade de São Paulo.

CAVALCANTI, Maria Laura Viveiros de Castro. 2007. "O buquê da noiva". Revista Festa Viva, 1(1):62-63. . 2012. "Luzes e sombras no dia social: o símbolo ritual em Victor Turner". Horizontes Antropológicos, 18(37):103-131. Disponível em: http://www.scielo.br/ scielo. php? script $=$ sci_arttext $\&$ pid $=$ S0104- 71832012000100005\&lng =en\&nrm =iso. Acesso em 07/10/2016.

CHARSLEY, Simon. 1992. Wedding cakes and cultural history. London, New York: Routledge.

DEL PRIORE, Mary. 2006. História do amor no Brasil. 2a . ed. São Paulo: Contexto. . 2013. Conversas e histórias de mulher. 1 ${ }^{a}$. ed. São Paulo: Planeta.

DAMAT TA, Roberto. 2000 . "Individualidade e liminaridade: considerações sobre os ritos de passagem e a modernidade". Revista Mana, 6(1):7-29. Disponível em: http://www.scielo.br/scielo. php? script $=$ sci_arttext $\&$ pid $=$ S010493132000000100001\&lng =en\&nrm =iso. Acesso em 07/10/2016.

DOUGLAS, Mary. 1984. Food in the social order: studies of food and festivities in three American communities. New York: Russel Sage Foundation.

DUMONT, Luis. 2008 . Homo hierarchicus: o sistema de castas e suas implicações. $2^{a}$. ed. São Paulo: Editora da Universidade de São Paulo.

ELIAS, Norbert. 1994. O processo civilizador. Vol. 1: Uma história dos costumes. Rio de Janeiro: Zahar. . 1993. O processo civilizador. Vol. 2: Formação do Estado e civilização. Rio de Janeiro: Zahar.

ESCOURA, Michele. 2016. "Vestida de noiva: marcadores de gênero e classe em movimento no mercado de festas de casamento entre São Paulo (SP) e Belém (PA)". Caxambu. $40^{\circ}$ Encontro Anual da Anpocs.

FALLABRINO, M. V. Perez. 2015. “Um banquete renascentista: o casamento de Lorenzo de Medici e Clarice Orsini". Revista História Helikon, 2(4):02-15. Disponível em: http:// www2.pucpr.br/reol/index.php/ 
helikon?dd99=pdf\&dd1=15865. Acesso em 07/10/2016.

FREYRE, Gilberto. 2007. Açúcar: uma sociologia do doce, com receitas de bolos e doces do Nordeste do Brasil. 5a. ed. São Paulo: Global.

GRAHAM, Maria. 1956. Diário de uma viagem ao Brasil. São Paulo: Companhia Editora Nacional.

JAMES, Allison. 1990. "The good, the bad and the delicious: the role of confectionery in British society". The Sociological Review, 38(4):666-688. Disponível em: http://onlinelibrary. wiley.com/doi/10.1111/j.1467954X.1990.tb00934.x/pdf. Acesso em 07/10/2016.

MACIEL, Maria Eunice. 2001. "Cultura e alimentação ou o que têm a ver os macaquinhos de Koshima com Brillat-Savarin". Horizontes Antropológicos, 7(16):145156. Disponível em: http://www. scielo.br/scielo.php? script $=\mathbf{s c i}$ a r t t ex t \& p i d = S 0104 71832001000200008\&lng=en\&nrm =iso. Acesso em 07/10/2016.

MARINS, Cristina. 2016. Quando o céu é o limite: um olhar antropológico sobre o universo dos casamentos e dos cerimonialistas. Niterói: Eduff.

MENESES, Erika. 2017. Consumo e indústria de casamentos: questões sobre os significados de uma instituição social e a ascensão de um mercado. Tese de Doutorado em Antropologia, Universidade Federal do Rio Grande do Sul, Porto Alegre.

MINTZ, Sidney W. 2001. "Comida e antropologia: uma breve revisão". Revista Brasileira de Ciências Sociais, 16(47):31-42. Disponível em: http://www.scielo.br/_scielo. php? script $=$ sci_arttext $\&$ pid $=$ S010269092001000300002\&lng =en\&nrm =iso. Acesso em 07/10/2016. . 2009. "Sugar: old champion, new contenders". Food Ethics, 4(2):510. Disponível em: http://www. foodethicscouncil.org/uploads/ publications/Magazine_4(2)_Full. pdf. Acesso em 07/10/2016.

SCHINO, Juni di. 2016. Arte dolciaria barocca: I segreti del credenziere di Alessandro VII. Roma: Gangemi Editore.

. 2014. "The significance and symbolism of sugar sculpture at Italian court banquets". In: Mark McWilliams (ed.), Food \& material culture: proceedings of the Oxford Symposium on food and cookery. Totnes: Prospect Books. pp. 111-122. SCHWARCZ, Lilia M. \& STARLING, Heloisa M. 2015. $1^{\mathrm{a}}$. ed. Brasil: uma biografia. São Paulo: Companhia das Letras.

STRONG, Roy. 2004. Banquete: uma história ilustrada da culinária, dos costumes e da fartura à mesa. Rio de Janeiro: Jorge Zahar Ed.

TURNER, Victor. 1968. The drums of affliction: a study of religious processes among the Ndembu of Zambia. Oxford: Oxford University Press.

.2005. Floresta de símbolos: aspectos do ritual ndembu. Niterói: Editora da Universidade Federal Fluminense. . 2013. O processo ritual: estrutura e antiestrutura. $2^{\mathrm{a}}$. ed. Petrópolis: Vozes.

VAN GENNEP, Arnold. 2011. Ritos de passagem. Os ritos de passagem: estudo sistemático dos ritos da porta e da soleira, da hospitalidade, da adoção, gravidez e parto, nascimento, infância, puberdade, iniciação, ordenação, coroação, noivado, casamento, funerais, estações etc. $3^{\mathrm{a}}$. ed. Petrópolis: Vozes.

WILSON, Monica. 1972. "The wedding cakes: a study of ritual change". In: Jean Sybil (org.), The interpretation of ritual: essays in honour of $A$. I. Richards. New York: Tavistok Publications. pp. 107-201. 
COM AÇÚCAR, COM AFETO: UM

OLHAR ANTROPOLÓGICO SOBRE

RITUAIS MATRIMONIAIS A PARTIR DE SUAS MESAS DE DOCES

\begin{abstract}
Resumo
Neste artigo, argumento que as mesas de doces presentes nos rituais matrimoniais ocupam lugar central nos festejos que se seguem à cerimônia de casamento e são atravessadas por dimensões econômicas, morais, materiais, estéticas e afetivas, funcionando como um condensador do ritual. Defendo ainda que, quando observadas atentamente, as mesas de doces são reveladoras da existência de uma hierarquia presente em todo o ritual, bem como de uma temporalidade que é própria dele. Nos últimos anos, venho me dedicando a estudar este ritual de passagem com o intuito de compreender alguns dos significados, códigos e valores nele investidos. O exame do percurso da mesa de doces, desde sua montagem até sua desmontagem, focalizando em especial suas funções sociais e simbólicas, é realizado a partir de material etnográfico construído entre os anos 2011 e 2014.
\end{abstract}

Palavras-chave: Rituais matrimoniais; Ritos de passagem; Doces; Casamento.

\author{
AN ANTHROPOLOGICAL APPROACH \\ TO CONFECTIONERY ITEMS \\ DISPLAYED IN WEDDING RITUALS
}

\begin{abstract}
Sweets play an important role in Brazilian weddings. I argue in this paper that confectionery items occupy a central place in wedding festivities. Sweets, traditionally displayed on fixed items of furniture, are generally known as "mesas de doces" and encapsulate economic, moral, material, aesthetic and emotional dimensions. Moreover, I suggest that close observation of confectionary in weddings points to the existence of a specific hierarchy as well a particular sense of time. Since in recent years I have attempted to understand some of the meanings, codes and values invested in Brazilian weddings, this paper rests on ethnographic material collected between 2011 and 2014.
\end{abstract}

Key words: Wedding rituals; Rites of passage; Sweets; Wedding. 
UNA PERSPECTIVA

ANTROPOLÓGICA DE LOS DULCES

EXISTENTES EN RITUALES

MATRIMONIALES

\section{Resumen}

En este artículo sostengo que las "mesas de dulces" presentes en rituales de fiestas de matrimonio ocupan un lugar central en banquetes de bodas y están atravesados por dimensiones económicas, morales, estéticas y afectivas, funcionando como un condensador del ritual. También señalo que, cuando son observados atentamente, los dulces son capaces de revelar una jerarquía del ritual, así como una temporalidad que le es propia. En los últimos años vengo estudiando este rito de pasaje con la intención de comprender algunos de sus sentidos, códigos y valores. El análisis del circuito de la "mesa de dulces", desde su montaje y desmontaje, enfocando especialmente sus funciones sociales y simbólicas, es realizado a partir del material etnográfico construido entre 2011 y 2014.

Palabras clave: Rituales matrimoniales; Ritos de pasaje; Dulces; Bodas. 